\title{
Comprehensive elaboration of glycemic variability in diabetic macrovascular and microvascular complications
}

\author{
Bao Sun ${ }^{1,2}$, Zhiying Luo ${ }^{1,2^{*}}$ and Jiecan Zhou ${ }^{3^{*}}$
}

\begin{abstract}
Diabetes mellitus is the major risk factor for the development of macrovascular and microvascular complications. It is increasingly recognized that glycemic variability (GV), referring to oscillations in blood glucose levels and representing either short-term or long-term GV, is involved in the pathogenesis of diabetic complications and has emerged as a possible independent risk factor for them. In this review, we summarize the metrics and measurement of GV in clinical practice, as well as comprehensively elaborate the role and related mechanisms of GV in diabetic macrovascular and microvascular complications, aiming to provide the mechanism-based therapeutic strategies for clinicians to manage diabetes mellitus.
\end{abstract}

Keywords: Glycemic variability, Diabetes mellitus, Diabetic macrovascular and microvascular complications, Therapeutic strategies

\section{Introduction}

Diabetes mellitus characterized by hyperglycemia is a major chronic metabolic disorder primarily caused by defects in insulin secretion, insulin action or both [1]. Globally, it is estimated that 463 million people have diabetes and this number is projected to reach 700 million by 2045 [2]. These individuals have at least a twofold increased risk of cardiovascular events compared with those without diabetes mellitus, playing a leading role in diabetes-related morbidity and mortality [3-5]. Moreover, diabetes mellitus contributes to the development of macrovascular complications, such as coronary artery disease, peripheral vascular disease and cerebrovascular disease, and microvascular complications, including retinopathy, nephropathy and neuropathy [6].

\footnotetext{
*Correspondence: Izhy199089@csu.edu.cn; skykx2008@163.com

${ }^{1}$ Department of Pharmacy, The Second Xiangya Hospital, Central South

University, No. 139 Middle Renmin Road, Changsha 410011, Hunan, China

${ }^{3}$ Institute of Clinical Medicine, The First Affiliated Hospital, University

of South China, No. 69, Chuanshan Road, Hengyang 421001, Hunan, China

Full list of author information is available at the end of the article
}

Although HbA1c remains the gold-standard assay for assessing glycemic control, it is not a complete expression of glycemic status [7]. Glycemic variability (GV), representing an integral component of glucose homoeostasis, is emerging as an important metric to assess glycemic control in clinical practice and without doubt now being recognized [8]. Recent epidemiological evidence suggested that GV was associated with higher risk for cardiovascular events among individual with diabetes mellitus, and the biological plausibility of the association between $\mathrm{GV}$ and the progression of diabetic vascular complications had been proposed [9-12]. However, the importance of GV on diabetic complications is still under debate due to inconclusive evidence $[13,14]$.

Our previous study also indicated that GV was associated with cardiovascular events and hypoglycemia [15, 16]. Although it has not yet been clearly identified as an independent risk factor for diabetic complications, the role of GV in diabetic complications has attracted a lot of attention. In this review, we summarize the main categories and measurement of GV in clinical practice, as well as comprehensively elaborate the role and 
related mechanisms of $\mathrm{GV}$ in diabetic macrovascular and microvascular complications, aiming to provide the mechanism-based therapeutic strategies for clinicians to manage diabetes mellitus.

\section{Metrics and measurement of GV}

Generally, GV is defined by the measurement of fluctuations of glucose or other related parameters of glucose homoeostasis within a given time interval. However, currently, there is no consensus on the optimum method to characterize GV [17]. Although various metrics quantifying GV have been introduced, many of them are not well understood $[14,18]$. Therefore, metrics that effectively describes GV will be desirable. There are mainly two categories of metrics: long-term GV, based on serial determinations over a longer period of time, usually involving HbA1c, serial fasting plasma glucose (FPG) and postprandial glucose (PPG) measurements, and short-term $\mathrm{GV}$, assessed by both within-day and between-day GV (Table 1).

\section{Long-term GV}

Long-term GV is usually based on visit-to-visit measurements of HbA1c, FPG and PPG, with the subsequent calculation of their coefficient of variation $(\mathrm{CV})$ and standard deviation (SD) [19]. Moreover, studies indicated that long-term GV was partly a reflection of surrounding hyperglycemia because measures of long-term GV correlated with either mean concentration of blood glucose or mean HbA1c [20, 21]. In recent years, variation independent of the mean (VIM), which was calculated based on logarithmic curve fitting (the natural logarithm of SD over the natural logarithm of the mean) to eliminate its correlation with mean level, was also used to measure long-term GV [22].

\section{Short-term GV}

Short-term GV characterized by sudden and rapid upward or downward glucose changes mainly includes within-day and between-day GV.

Table 1 The metrics and measure of GV

\begin{tabular}{|c|c|c|}
\hline Various metrics and measure of GV & Description or definition & References \\
\hline \multicolumn{3}{|l|}{ Long-term GV } \\
\hline $\mathrm{CV}$ & Variation around the mean blood glucose of $\mathrm{HbA1c}$, FPG and PPG between sequential visits & {$[19]$} \\
\hline SD & $\begin{array}{l}\text { Magnitude of variability relative to mean blood glucose of } \mathrm{HbA1c} \text {, FPG and PPG between sequen- } \\
\text { tial visits }\end{array}$ & [19] \\
\hline VIM & $\begin{array}{l}\text { Based on logarithmic curve fitting (the natural logarithm of SD over the natural logarithm of the } \\
\text { mean) }\end{array}$ & {$[22]$} \\
\hline \multicolumn{3}{|l|}{ Short-term GV } \\
\hline \multicolumn{3}{|l|}{ Within-day or between-day GV } \\
\hline CV & Variation around the mean blood glucose & {$[18]$} \\
\hline SD & Magnitude of variability relative to mean blood glucose & {$[18]$} \\
\hline LBGl/HBGl & Measure of frequency and magnitude of hypoglycemia or hyperglycemia & {$[31]$} \\
\hline ADRR & Sum of the daily peak risks for hypoglycemia and hyperglycemia & {$[32]$} \\
\hline \multicolumn{3}{|l|}{ Within-day GV } \\
\hline MAGE & Mean differences from peaks to nadirs & {$[23]$} \\
\hline MAG & Absolute differences between sequential readings divided by the time & [8] \\
\hline CONGA & Difference between a current blood glucose reading and a reading taken hours earlier & {$[25]$} \\
\hline TIR & $\begin{array}{l}\text { Percentage of time spent within the target glucose range of } 3.9-10.0 \mathrm{mmol} / \mathrm{L} \text { during a } 24-\mathrm{h} \\
\text { period }\end{array}$ & {$[26,27]$} \\
\hline \multicolumn{3}{|l|}{ Between-day GV } \\
\hline MODD & Absolute differences between two glucose values measured at the same time with a $24 \mathrm{~h}$ interval & {$[28]$} \\
\hline AGP/IQRs & Distribution of glucose data at a given timepoint & {$[29,30]$} \\
\hline \multicolumn{3}{|l|}{ Measuring method of GV } \\
\hline SMBG & Reflected blood glucose fluctuations on the timescale of hours or days & {$[20]$} \\
\hline CGM & Interstitial glucose measurements at 5 min intervals & {$[20,34]$} \\
\hline Flash glucose monitoring & Measured interstitial glucose and indicated direction and speed of glucose change & {$[36]$} \\
\hline
\end{tabular}

GV glycemic variability, CV coefficient of variation, SD standard deviation, FPG fasting plasma glucose, PPG postprandial glucose, VIM variation independent of the mean, $L B G$ low blood glucose index, $H B G$ l high blood glucose index, $A D R R$ average daily risk range, MAGE mean amplitude of glycemic excursions, MAG mean absolute glucose, CONGA continuous overlapping net glycemic action, $T I R$ time in range, $M O D D$ mean of daily differences, $A G P$ average glucose profile, IQRs interquartile ranges, SMBG self-monitoring of blood glucose, CGM continuous glucose monitoring 


\section{Within-day GV}

Similar to long-term GV, SD and CV are also the common metrics of short-term GV. When averaging daily SD or $\mathrm{CV}$, the mean of within-day daily GV can also be estimated over the stated time [18]. Mean amplitude of glycemic excursions (MAGE) was the first to be developed, primarily to assess mealtime-related glucose excursions [23], and was the gold standard for assessing the shortterm within-day GV [24]. Due to its simplicity, MAGE was widely used to assess within-day GV by measuring the arithmetic mean of the differences between consecutive peaks and nadirs. Mean absolute glucose (MAG) was another metric of within-day GV that summed absolute differences between sequential readings divided by the time between the first and last blood glucose measurement [8]. In addition, a novel measurement of withinday GV was presented by the continuous overlapping net glycemic action (CONGA) that calculated the SD of difference between a current blood glucose reading and a reading taken hours earlier [25]. Recently, time in range (TIR), referring to the percentage of time spent within the target glucose range of $3.9-10.0 \mathrm{mmol} / \mathrm{L}$ during a 24-h period, was identified as a key metric of within-day GV $[26,27]$.

\section{Between-day GV}

Mean of daily differences (MODD) was considered to be the best metric for estimating the between-day GV [28]. This metric was based on the calculation of the absolute differences between two glucose values measured at the same time within a $24 \mathrm{~h}$ interval. Another metric of between-day GV was average glucose profile (AGP), which reflected the presence or absence of day-to-day synchrony in glucose patterns over a 14-day period and reported the results as interquartile ranges (IQRs) [29, 30].

Of note, particular attention should be given to the low blood glucose index (LBGI), high blood glucose index (HBGI) and average daily risk range (ADRR), as they were logarithmic calculations designed to evaluate the tendency to hypo or hyperglycemia, which reflected either within-day GV or between-day GV. LBGI and HBGI were preceded by a log transform to render symmetric the skewed distribution of glucose values to predict hypoglycemia or hyperglycemia [18, 31]. Meanwhile, ADRR was sum of the daily peak risks for hypo- and hyperglycemia [32].

Notably, the measuring method of GV was different in the last few years. The traditional approach to measuring GV relied on self-monitoring of blood glucose (SMBG) [20], but this method had been gradually replaced by continuous glucose monitoring (CGM) over the past few years [33-35]. Compared with SMBG, CGM with interstitial glucose measurements at $5 \mathrm{~min}$ intervals provides a more comprehensive record during the day and night periods [20, 34]. In recent years, Chico et al. reported that flash glucose monitoring, a new approach to glucose monitoring, had a long sensor lifetime of 14 days and emerged as a practical solution to the glucose monitoring [36].

\section{The role of GV in diabetic macrovascular and microvascular complications}

There is growing evidence supporting that GV has drawn a great attention for its role in diabetic macrovascular and microvascular complications [15, 37-41]. Among type 2 diabetes mellitus (T2DM) patients from the Hoorn Diabetes Care System cohort, the individuals with a higher visit-to-visit GV had an unfavorable metabolic profile and had an increased risk of macrovascular and macrovascular complications as well as mortality [42].

\section{GV and diabetic macrovascular complications}

It is generally accepted that macrovascular complications include coronary artery disease, peripheral vascular disease and cerebrovascular disease. A meta-analysis found that homeostasis model assessment of insulin resistance (HOMA-IR) and reduced intima-media thickness (IMT) level were the cardiovascular disease (CVD) risk factors and were significantly lower in low glucose variability group than in high glucose variability group [43]. Minimizing GV could improve insulin resistance and reduce IMT, consistent with a lowering in risk of CVD. Moreover, a post hoc cohort analysis including 160 patients with or without diabetes mellitus showed that post-procedural GV assessed by calculating the mean daily $\delta$ blood glucose during the first 2 days after transcatheter aortic valve implantation was associated with an increased risk of macrovascular complications (e.g., death, stroke and myocardial infarction) [44]. Similarly, a retrospective study enrolling 2215 patients who underwent coronary artery bypass grafting reported that increased 24-h but not 12-h postoperative GV was a predictor of major adverse events [45]. Benalia et al. revealed that T2DM patients admitted for acute myocardial infarction with elevated GV had significantly higher SYNTAX scores [46]. SYNTAX scores, which characterized coronary artery lesion severity, were independently related to high GV beyond HbA1c levels, suggesting that GV was associated with coronary artery disease severity and the early evaluation of GV might serve as a therapeutic target for both primary and secondary prevention [46]. Analogously, intraday GV calculated by MAGE was independently associated with coronary artery spasm in patients with dysglycemia [47]. Another meta-analysis 
showed that higher MAGE at admission was associated with higher risk of major adverse cardiovascular events in coronary artery disease patients regardless of the diabetic status [48]. Although GV was correlated with macrovascular complications to some extent, combining GV and HbA1c might exert incremental effects. Nusca et al. found that combining GV and HbA1c could identify the individuals at higher thrombotic risk among patients with T2DM undergoing percutaneous coronary intervention [49]. Recently, the Glycemia in Acute Stroke II (GLIASII) translational study was performed to evaluate the impact of GV on acute ischaemic stroke (IS) outcomes and examine the impact of intravenous or subcutaneous insulin on GV in an animal model of IS by using continuous subcutaneous monitoring devices [50], which might overcome the main limitations of the prior studies.

Consistent with the metrics of short-term GV, longterm GV was also correlated with the diabetic macrovascular complications. A prospective study by Gerbaud and his colleagues found that long-term GV assessed by SD during initial hospitalization was the strongest independent predictive factor for midterm major cardiovascular events in patients with diabetes [51]. Similarly, another prospective cohort study including 53,607 Chinese participants reported that elevated visit-to-visit FPG variability defined as the CV of FPG significantly increased the risk of CVD and all-cause mortality [9], which was helpful for predicting the risk for CVD and all-cause mortality. A prospective cohort study including 455 patients with T2DM and with follow-up for a median of 4.7 years identified that FPG variability calculated by $\mathrm{CV}$ could be a novel risk factor for the long-term adverse changes in left cardiac structure and systolic function in patients with T2DM [52]. Even after additionally stratified by mean HbA1c levels, FPG-CV was still independently associated with the annualized changes in left cardiac structure and systolic function in patients with $\mathrm{HbA1c} \geq 7 \%$, while not in patients with $\mathrm{HbA} 1 \mathrm{c}<7 \%$. In the Veteran Affairs Diabetes Trial (VADT), FPG variability evaluated by $\mathrm{CV}$ and average real variability was significantly associated with CVD even after adjusting for the risk factors in patients with T2DM [10]. Moreover, Coronary Artery Risk Development in Young Adults (CARDIA) study suggested that higher long-term FPG variability assessed by $\mathrm{CV}$ during young adulthood before the onset of diabetes was associated with incident diabetes, macrovascular events and mortality [53]. Recently, Lee et al. showed that long-term FPG variability calculated by VIM was correlated with the risk of stroke, myocardial infarction, and all-cause mortality in patients with diabetes [54]. More importantly, the impact of FPG variability was higher in the elderly and those with a longer duration of diabetes and lower FPG levels. Yang et al. also found that visit-tovisit FPG variability measured by $\mathrm{CV}$ was an independent predictor of incidence of left ventricular adverse remodeling in T2DM patients with ST-segment elevation myocardial infarction [55]. Assessing FPG variability by other two measures, including SD and VIM, yielded similar findings. Along with the variability of FPG, long-term variability of $\mathrm{HbA} 1 \mathrm{c}$ was also associated with the risk of macrovascular complications. A previous study enrolling 632 patients with T2DM revealed that long-term HbA1c variability (assessed by CV and VIM) and systolic blood pressure contributed to a combined and additive risk for CVD in patients with T2DM [56]. In Chinese T2DM patients, long-term $\mathrm{HbA1c}$ variability was calculated as intra-individual mean, SD, CV and adjusted SD, and was associated with macrovascular complication [57], and long-term stabilization of glucose is important in diabetes management, especially in the early stage of atherosclerosis. Meaningfully, a retrospective cohort study provided a support that $\mathrm{HbA1c}$ variability evaluated by $\mathrm{SD}$ and $\mathrm{CV}$ was associated with the presence of new-onset symptomatic heart failure with preserved ejection fraction (HFpEF) in patients with T2DM [58]. Analogously, Gu et al. showed that higher HbA1c variability (measured by $\mathrm{SD}$ and $\mathrm{CV}$ ) was associated with higher all-cause mortality or composite endpoints, and was an independent predictor of all-cause mortality or composite endpoints [59]. Interestingly, Yokota et al. found the consistent results and suggested that reducing GV might represent a potential new therapeutic strategy for the prevention of HFpEF in T2DM patients [60]. Recent studies also addressed the importance of long-term HbA1c variability. The study enrolled 420 T2DM patients and suggested that visit-to-visit $\mathrm{HbA1c}$ variability expressed as $\mathrm{SD}, \mathrm{CV}$ and VIM was independently associated with incidence of in-stent restenosis in patients with T2DM after stent implantation [61]. Of note, several studies disclosed that long-term GV including both HbA1c and FPG variability (calculated by $\mathrm{CV}$ ) was associated with peripheral artery disease risk and accelerated progression of coronary atherosclerosis in patients with T2DM [62,63]. These clinical results addressed the essential role of GV in diabetic macrovascular complications (Table 2), and paved the way for the research on relevant mechanisms.

\section{GV and diabetic microvascular complications}

Diabetic nephropathy (DN), diabetic peripheral neuropathy (DPN) and diabetic retinopathy (DR) are the main microvascular complications caused by chronic hyperglycemia [6]. As with diabetic macrovascular complications, GV also played a crucial role in diabetic microvascular complications (Table 3). 
Table 2 The role of GV in diabetic macrovascular

\begin{tabular}{|c|c|c|c|c|}
\hline Metrics of GV & Measuring method & Individuals & Main results & References \\
\hline Mean daily $\delta$ blood glucose & SMBG & $\begin{array}{l}160 \text { patients with or without } \\
\text { diabetes }\end{array}$ & $\begin{array}{l}\text { Increased risk of macrovascular } \\
\text { complications }\end{array}$ & [44] \\
\hline MAGE & SMBG & $\begin{array}{l}204 \text { patients with poorly controlled } \\
\text { T2DM }\end{array}$ & $\begin{array}{l}\text { Associated with coronary artery } \\
\text { disease severity }\end{array}$ & [46] \\
\hline MAGE & Flash glucose monitoring & 50 patients with dysglycemia & $\begin{array}{l}\text { Positively correlated with coronary } \\
\text { artery spasm }\end{array}$ & [47] \\
\hline MAGE and CV & CGM & $\begin{array}{l}35 \text { T2DM patients on clopidogrel } \\
\text { therapy }\end{array}$ & $\begin{array}{l}\text { Provided additional diagnostic sig- } \\
\text { nificance in identifying diabetic } \\
\text { patients with HPR }\end{array}$ & [49] \\
\hline SD of blood glucose & SMBG & $\begin{array}{l}327 \text { patients with diabetes and } \\
\text { acute coronary syndrome }\end{array}$ & $\begin{array}{l}\text { An independent predictive factor } \\
\text { for midterm major cardiovascular } \\
\text { events }\end{array}$ & [51] \\
\hline CV of FPG & SMBG & 455 patients with T2DM & $\begin{array}{l}\text { A novel risk factor for left cardiac } \\
\text { structure and systolic function }\end{array}$ & [52] \\
\hline $\begin{array}{l}\text { CV and average real variability of } \\
\text { FPG }\end{array}$ & SMBG & 1791 individuals with T2DM & $\begin{array}{l}\text { Significantly associated with } \\
\text { cardiovascular disease }\end{array}$ & [10] \\
\hline CV of FPG & SMBG & 3769 individuals & $\begin{array}{l}\text { Significantly associated incident } \\
\text { diabetes, macrovascular events } \\
\text { and mortality }\end{array}$ & [53] \\
\hline VIM of FPG & SMBG & 624,237 subjects with diabetes & $\begin{array}{l}\text { Increased the risk of stroke, myo- } \\
\text { cardial infarction, and all-cause } \\
\text { mortality }\end{array}$ & [54] \\
\hline CV of visit-to-visit FPG & SMBG & $\begin{array}{l}437 \text { patients with T2DM and ST- } \\
\text { segment elevation myocardial } \\
\text { infarction }\end{array}$ & $\begin{array}{l}\text { Independently predicted the inci- } \\
\text { dence of left ventricular adverse } \\
\text { remodeling }\end{array}$ & [55] \\
\hline $\mathrm{CV}$ and $\mathrm{VIM}$ of $\mathrm{HbA} 1 \mathrm{C}$ & SMBG & $\begin{array}{l}632 \text { patients with T2DM and no his- } \\
\text { tory of cardiovascular disease }\end{array}$ & $\begin{array}{l}\text { Increased the combined and addi- } \\
\text { tive risk for cardiovascular disease }\end{array}$ & [56] \\
\hline $\begin{array}{l}\text { Intra-individual mean, SD and CV } \\
\text { of } \mathrm{HbA} 1 \mathrm{C}\end{array}$ & SMBG & $\begin{array}{l}5278 \text { diabetic patients with no } \\
\text { history of cardiovascular disease } \\
\text { and atherosclerosis }\end{array}$ & $\begin{array}{l}\text { Positively associated with macro- } \\
\text { vascular complications }\end{array}$ & [57] \\
\hline $\mathrm{SD}$ and $\mathrm{CV}$ of $\mathrm{HbA} 1 \mathrm{c}$ & SMBG & $\begin{array}{l}201 \text { subjects with T2DM and arte- } \\
\text { rial hypertension }\end{array}$ & $\begin{array}{l}\text { Potentially predicted the progres- } \\
\text { sion of HFpEF }\end{array}$ & [58] \\
\hline $\mathrm{SD}$ and $\mathrm{CV}$ of $\mathrm{HbA} 1 \mathrm{c}$ & SMBG & $\begin{array}{l}902 \text { patients with heart failure and } \\
\text { T2DM }\end{array}$ & $\begin{array}{l}\text { An independent predictive factor } \\
\text { of all-cause mortality or compos- } \\
\text { ite endpoints }\end{array}$ & [59] \\
\hline $\mathrm{SD}$ of $\mathrm{HbA} 1 \mathrm{c}$ & CGM & $\begin{array}{l}100 \text { type } 2 \text { diabetic patients with } \\
\text { preserved left ventricular ejection } \\
\text { fraction }\end{array}$ & $\begin{array}{l}\text { Associated with poor left ventricu- } \\
\text { lar diastolic dysfunction }\end{array}$ & [60] \\
\hline $\mathrm{CV}, \mathrm{SD}$ and $\mathrm{VIM}$ of $\mathrm{HbA} 1 \mathrm{c}$ & SMBG & $\begin{array}{l}420 \text { diabetic patients after stent } \\
\text { implantation }\end{array}$ & $\begin{array}{l}\text { Independent predicted the inci- } \\
\text { dence of in-stent restenosis }\end{array}$ & [61] \\
\hline $\mathrm{CV}$ of $\mathrm{HbA} 1 \mathrm{c}$ and $\mathrm{FPG}$ & SMBG & 396 patients with T2DM & $\begin{array}{l}\text { Positively associated with acceler- } \\
\text { ated progression of coronary } \\
\text { atherosclerosis }\end{array}$ & [62] \\
\hline $\mathrm{CV}$ of $\mathrm{HbA} 1 \mathrm{c}$ and $\mathrm{FPG}$ & SMBG & $\begin{array}{l}\text { 63,084 Chinese individuals with } \\
\text { diabetes }\end{array}$ & $\begin{array}{l}\text { Increased peripheral artery disease } \\
\text { risk }\end{array}$ & [63] \\
\hline
\end{tabular}

SMBG self-monitoring of blood glucose, MAGE mean amplitude of glycemic excursions, T2DM type 2 diabetes mellitus, CV coefficient of variation, CGM continuous glucose monitoring, HPR high platelet reactivity, SD standard deviation, FPG fasting plasma glucose, VIM variation independent of the mean, HFpEF heart failure with preserved ejection fraction

\section{The role of GV in DN}

An analysis based on three large and well-designed clinical trials demonstrated a consistent finding that FPG variability was correlated with increased risk for moderate to severe DN [64]. Within the Association of Clinical Diabetologists Annals database, Ceriello et al. identified that high variability in HbA1c (assessed by SD) conferred the highest risk of developing albuminuria, contributing to the development of diabetic kidney disease [65]. Similarly, another study also confirmed that HbA1c_CV was an independent risk factor for deterioration of renal function, and early minimization of GV could curb deterioration of renal function [66]. Subsequent studies addressed that the long-term intra-individual variability 
Table 3 The role of GV in diabetic microvascular

\begin{tabular}{|c|c|c|c|c|}
\hline Metrics of GV & Measuring method & Individuals & Main effects & References \\
\hline $\mathrm{SD}$ of $\mathrm{HbA} 1 \mathrm{c}$ & $\mathrm{SMBG}$ & $\begin{array}{l}4231 \text { patients with T2DM and } \\
\text { albuminuria }\end{array}$ & Increased the risk of albuminuria & {$[65]$} \\
\hline CV of $\mathrm{HbA} 1 \mathrm{c}$ & SMBG & 1383 T2DM patients & $\begin{array}{l}\text { An independent risk factor for } \\
\text { deterioration of renal function }\end{array}$ & {$[66]$} \\
\hline $\mathrm{SD}$ of $\mathrm{HbA} 1 \mathrm{c}$ & SMBG & $\begin{array}{l}388 \text { patients with diabetes and } \\
\text { chronic kidney disease }\end{array}$ & $\begin{array}{l}\text { Positively associated with the } \\
\text { risk of chronic kidney disease } \\
\text { progression }\end{array}$ & {$[68]$} \\
\hline $\mathrm{SD}$ of $\mathrm{HbA} 1 \mathrm{c}$ & SMBG & 604 patients with T2DM & $\begin{array}{l}\text { Significantly associated with pro- } \\
\text { gression of DN }\end{array}$ & {$[69]$} \\
\hline MAGE & CGM & 40 patients with T1DM or T2DM & An independent risk factor for DPN & {$[70]$} \\
\hline $\mathrm{TIR}$ & Flash glucose monitoring & $\begin{array}{l}364 \text { individuals with diabetic } \\
\text { peripheral neuropathy }\end{array}$ & $\begin{array}{l}\text { Negatively correlated with the risk } \\
\text { of painful DN }\end{array}$ & {$[71]$} \\
\hline CV of visit-to visit FPG & SMBG & 2773 patients with T2DM & Increased the risk of DPN & {$[72]$} \\
\hline CV of visit-to visit FPG & $\mathrm{SMBG}$ & 36,152 individuals with T2DM & Potent predictors of DPN & {$[73]$} \\
\hline $\mathrm{CV}$ and mean of $\mathrm{HbA} 1 \mathrm{c}$ & SMBG & 563 T2DM patients & $\begin{array}{l}\text { Significantly increased the risk of } \\
\text { DPN }\end{array}$ & {$[74]$} \\
\hline $\begin{array}{l}\text { Intrapersonal mean, SD and CV of } \\
\text { HbA1c }\end{array}$ & SMBG & 238 patients with T2DM & $\begin{array}{l}\text { Strongly associated with the } \\
\text { degree of severity of cardiovas- } \\
\text { cular autonomic neuropathy }\end{array}$ & {$[75]$} \\
\hline $\begin{array}{l}\text { Intrapersonal mean, SD and CV of } \\
\text { HbA1c }\end{array}$ & $\mathrm{SMBG}$ & 223 patients with T2DM & $\begin{array}{l}\text { Strongly associated with the sever- } \\
\text { ity of peripheral neuropathy }\end{array}$ & {$[76]$} \\
\hline $\mathrm{TIR}$ & CGM & 3262 patients with T2DM & $\begin{array}{l}\text { Inversely correlated with the sever- } \\
\text { ity of DR }\end{array}$ & {$[78]$} \\
\hline $\mathrm{CV}$ and $\mathrm{SD}$ of $\mathrm{HbA} 1 \mathrm{c}$ & $\mathrm{SMBG}$ & 220 patients with T1DM & $\begin{array}{l}\text { Positively associated with DR and } \\
\text { impaired renal function }\end{array}$ & [80] \\
\hline CV of $\mathrm{HbA} 1 \mathrm{c}$ & SMBG & 415 patients with T1DM & $\begin{array}{l}\text { Independently associated with the } \\
\text { risk of DR development }\end{array}$ & {$[81]$} \\
\hline
\end{tabular}

$S D$ standard deviation, $S M B G$ self-monitoring of blood glucose, T2DM type 2 diabetes mellitus, $C V$ coefficient of variation, $D N$ diabetic neuropathy, MAGE mean amplitude of glycemic excursions, CGM continuous glucose monitoring, DPN diabetes peripheral neuropathy, T1DM type 1 diabetes mellitus, TIR time in range, FPG fasting plasma glucose, $D R$ diabetic retinopathy

in $\mathrm{HbA1c}$, lipid parameters, uric acid and blood pressure played a greater role in the progression of chronic kidney disease (CKD) than the absolute value of each single variable, clarifying the important role of long-term intraindividual variability in progression of CKD [67]. A longitudinal study showed that greater HbA1c variability with a decreasing trend of HbA1c was defined as the SD of HbA1c and was associated with a lower risk of progression to dialysis in the patients with stages 3-4 CKD and poor glycemic control [68]. Noteworthily, there were differences in the risk factors for the progression of DR and $\mathrm{DN}$ in T2DM, and an observational study discovered that average $\mathrm{HbA1c}$ was significantly associated with progression of DR, whereas HbA1c variability (evaluated by SD) was significantly associated with progression of DN [69]. However, the initiation and progression of albuminuria are not included in the definition of DN progression in this observational study. Strikingly, Lachin et al. showed that within-day GV, as determined from quarterly glucose profiles, did not participant in the development of microvascular complications [20]. Thus, further prospective studies are required to confirm these discordances.

\section{The role of GV in DPN}

Short-term GV was estimated by MAGE in CGM and was found to be independently associated with a higher risk of DPN with type 1 or 2 diabetes [70], but the study had a small sample size, which might not be able to evaluate patients with severe diabetes complications. Yang et al. found that a decreasing level of TIR was significantly associated with an increasing risk of painful diabetic neuropathy, which might be underscored as a valuable clinical evaluation measure [71]. Investigators of a retrospective study reported that long-term variability as evaluated by FPG-CV was associated to the risk of painful DPN in patients with T2DM [72]. Consistent with this result, several studies found that HbA1c, FPG$\mathrm{CV}$ and HbA1c-CV increased risks of DPN and were potent predictors of DPN in T2DM patients [73, 74], which might play a crucial role in clinical risk assessments. Recent studies revealed that HbA1c variability calculated by SD was independently associated with the severity of peripheral neuropathy and cardiovascular autonomic neuropathy in patients with T2DM [75, 76]. Conversely, a cross-sectional study including 133 young 
adults with type 1 diabetes mellitus (T1DM) suggested that GV might not be a risk factor for diabetic neuropathy [77]. Longitudinal studies are required to confirm the elaborated role of GV in the progression of DPN.

\section{Roles of GV in DR}

Among a total of 3262 patients with T2DM, Lu et al. indicated that TIR measured by CGM was significantly associated with all stages of DR [78]. In the Rio De Janeiro Type 2 Diabetes Cohort Study, long-term visitto-visit GV, particularly the 24-month parameters either estimated by $\mathrm{HbA} 1 \mathrm{c}$ or FPG, could predict retinopathy progression in patients with good glycemic control (HbAlc $\leq 7.5 \%, 58 \mathrm{mmol} / \mathrm{mol})$ and predicted new-incident peripheral neuropathy [38]. A recent meta-analysis showed that high FPG variability (assessed by median or mean FPG variability levels) was strongly associated with the risk of retinopathy [odds ratio $(\mathrm{OR})=3.68$; $95 \%$ CI 1.01-13.4] in patients with T2DM [79]. Nevertheless, for elderly patients with T2DM, FPG variability did not increase the progression of DR [79]. On the other hand, long-term variability of $\mathrm{HbA} 1 \mathrm{c}$ assessed by $\mathrm{CV}$ or mean value was closely associated with DR (OR: 8.93 ; 95\%CI $1.86-42.87$ ), suggesting that both good and stable glycemic status might be important to prevent microvascular complications [80]. Due to the wide confidence intervals and the high heterogeneity, further studies are needed to confirm these conclusions. Recently, Schreur et al. performed a long duration of follow-up study and found that long-term HbA1c variability (defined as $\mathrm{CV}$ ) was one of the risk factors for the development and progression of DR in patients with T1DM [81].

\section{Relevant mechanisms of GV in diabetic macrovascular and microvascular complications}

Although accumulated clinical evidence described the association of GV and diabetic macrovascular and microvascular complications, the relevant mechanisms are multiple and indistinct. Previous studies demonstrated that GV was associated with the risk of both hyperglycemia and hypoglycemia [32, 82-84]. Increasing evidence has shown that GV, hypoglycemia and hyperglycemia are all closely related to oxidative stress $[85,86]$. It is noteworthy that transient hyperglycemia has been shown to induce even more vascular damage than sustained hyperglycemia, mainly mediated by oxidative stress [ 87 , 88]. Further, several researches indicated that transient hyperglycemia might cause epigenetics changes, such as cellular metabolic memory [89, 90], increasing insulin resistance and pancreatic $\beta$-cell dysfunction and apoptosis [91, 92]. Strikingly, Costantino et al. demonstrated that MAGE was independently associated with adverse epigenetic signatures on $\mathrm{p} 66^{\text {Shc }}$ promoter and promoted chromatin changes, leading to persistent vascular dysfunction in patients with T2DM and with target HbA1c levels [93]. Intriguingly, an animal experiment also demonstrated that higher GV displayed a more pronounced reactive oxygen species production and endothelial dysfunction [94]. More importantly, short-term glycemia fluctuations were reported to induce superoxide overproduction, inflammatory cytokines generation, increased oxidative stress and endothelial dysfunction and damage $[87,95,96]$, which contributed to chronic diabetic complications. Although oxidative stress has been considered as one of the underlying mechanisms for the effects of GV on diabetic complications [96-98], several studies have shown conflicting results $[99,100]$. These inconsistent results may be attributed to the differences in medications and the dissimilar methods used to determine oxidative stress, and further prospective researches are warranted to figure out these inconsistencies.

High GV has also been proven to be associated with the risk of hypoglycemia, which might be an independent cause of cardiovascular damage. Potential mechanisms by which hypoglycemia could lead to an increase in cardiovascular risk were manifested by release of inflammatory cytokines, increased platelet activation and endothelial dysfunction [101, 102]. Collectively, these results suggest that high GV increases the risk of hyperglycemia and hypoglycemia, subsequently inducing oxidative stress, inflammatory cytokines generation, epigenetics changes and endothelial dysfunction and damage, ultimately contributing to diabetic complications (Fig. 1).

\section{Mechanism-based therapeutic strategies}

There are several possible mechanism-based non-pharmacological and pharmacological strategies for reducing GV in clinical practice (Table 4).

\section{Non-pharmacological strategies}

CGM, either from real-time use or intermittently viewed, has beneficial effects on metabolic control, reducing risks of hyperglycemia and hypoglycemia, and decreasing GV, mean glucose concentration, and HbA1c values [103, 104]. The international consensus on the use of CGM highlighted the importance of assessing and reporting the percentages of TIR, time above range (TAR) and time below range (TBR) in conjunction with the evaluation of glucose control [34]. Moreover, a recent metaanalysis found that CGM could improve glycemic control by expanding TIR and decreasing GV, TBR and TAR in diabetes [105]. Additionally, previous studies suggested that exercise training, including resistance exercise and aerobic exercise, reduced GV and oxidative stress levels in patients with T2DM [106, 107]. Analogously, a recent study disclosed that two weeks of both high-intensity 


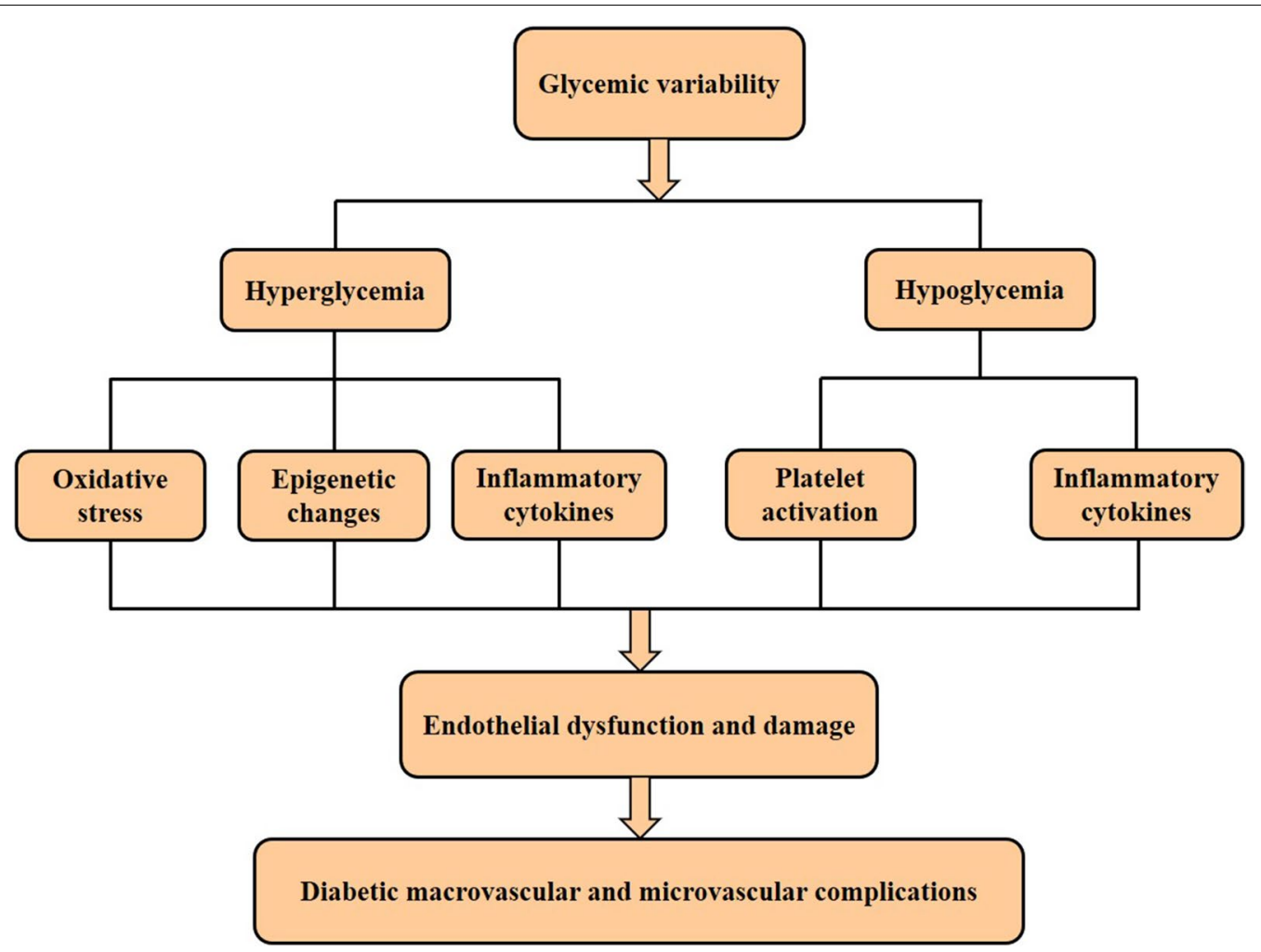

Fig. 1 Potential mechanisms of glycemic variability in diabetic macrovascular and microvascular

Table 4 Mechanism-based therapeutic strategies for reducing GV

\begin{tabular}{|c|c|c|c|}
\hline Strategies & Population & Possible mechanisms & References \\
\hline \multicolumn{4}{|l|}{ Non-pharmacological strategies } \\
\hline CGM & 40 patients with T1DM & Minimized the risk of severe hypoglycemia & [104] \\
\hline $\begin{array}{l}\text { High-intensity interval training and moderate- } \\
\text { intensity continuous training }\end{array}$ & $\begin{array}{l}15 \text { inactive overweight } \\
\text { or obese women }\end{array}$ & Decreased endothelial cell damage & [108] \\
\hline Aerobic and eccentric exercise & 16 healthy subjects & $\begin{array}{l}\text { Reduced inflammatory cytokines and oxidative stress } \\
\text { markers }\end{array}$ & [109] \\
\hline Low carbohydrate diet & 10 patients with T1DM & $\begin{array}{l}\text { Resulted in more time in euglycemia, less time in hypo- } \\
\text { glycemia }\end{array}$ & [110] \\
\hline \multicolumn{4}{|l|}{ Pharmacological strategies } \\
\hline Once-weekly trelagliptin and once-daily alogliptin & 27 patients with T2DM & $\begin{array}{l}\text { Improved glycemic control and reduced GV without } \\
\text { inducing hypoglycemia }\end{array}$ & [114] \\
\hline GLP-1 RA with basal insulin & 160 patients with T2DM & $\begin{array}{l}\text { Lowered hypoglycemia and might contribute to the } \\
\text { cardiovascular outcome reduction }\end{array}$ & [115] \\
\hline DPP4 inhibitors combined with metformin & 69 patients with T2DM & Reduced GV and hypoglycemia & [116] \\
\hline DPP4 inhibitors combined with metformin & 34 patients with T2DM & Reduced GV and hypoglycemia & [118] \\
\hline Metformin plus vildagliptin & 44 patients withT2DM & Attenuated oxidative stress index & [119] \\
\hline Empagliflozin as adjunct to insulin & 75 patients with T1DM & $\begin{array}{l}\text { Decreased glucose exposure and variability and increased } \\
\text { time in glucose target range. }\end{array}$ & {$[120]$} \\
\hline SGLT2 inhibitors & 15 patients with T1DM & Improved TIR and the mean glucose level and SD & [121] \\
\hline
\end{tabular}

CGM continuous glucose monitoring, T1DM type 1 diabetes mellitus, T2DM type 2 diabetes mellitus, GV glycemic variability, GLP-1 RA glucagon-like peptide 1 receptor agonist, DPP4 dipeptidyl-peptidase 4, SGLT2 sodium-glucose cotransporter 2 
interval training and moderate-intensity continuous training decreased GV and endothelial cell damage in obese women at elevated risk of T2DM [108]. Of note, both aerobic and eccentric exercise reduced GV in healthy individuals, which might be mediated by inflammatory cytokines and stress oxidative markers [109]. Another non-pharmacological strategy is dietary interventions. Low carbohydrate diet appeared to be sufficient to reduce postprandial hyperglycemia and improve glucose fluctuation, resulting in more time in euglycemia, less time in hypoglycemia and less GV [110-113].

\section{Pharmacological strategies}

Glucose-lowering drugs that achieve a target HbA1c and decrease the risk of hypoglycemia are crucial for the management of diabetes. A randomized pilot study concluded that once-weekly trelagliptin and once-daily alogliptin reduced GV and improved glycemic control without inducing severe treatment-emergent adverse events and hypoglycemia [114]. Particularly, greater benefits are shown in therapies combing new glucose-lowering drugs with metformin or insulin. The combination of basal insulin with a glucagon-like peptide 1 receptor agonist (GLP-1 RA) displayed the lowest GV and hypoglycemia in patients with T2DM, which might contribute to a reduction of cardiovascular outcome [115]. Furthermore, dipeptidyl peptidase 4 (DPP4) inhibitors combined with metformin therapy improved glucose level with a significantly greater reduction in GV and hypoglycemia [116-118]. Subsequently, a current study concluded that metformin plus vildagliptin therapy was more effective than metformin monotherapy by attenuating oxidative stress index [119]. Consistent results were obtained when combined sodium glucose cotransporter 2 (SGLT2) inhibitors with insulin therapy $[120,121]$. Empagliflozin as adjunct to insulin decreased glucose exposure and variability, as well as increased time in glucose target range in patients with T1DM [120]. Moreover, a retrospective cohort study unraveled that SGLT2 inhibitors improved TIR, SD and the mean glucose level without increasing the $\mathrm{TBR}<70 \mathrm{mg} / \mathrm{dL}$ in patients with T1DM [121]. In short, new antidiabetic drugs combined with basal insulin or metformin might be preferred pharmacological strategies for reducing hypoglycemia and oxidative stress, thus decreasing the incidence of diabetic complications.

\section{Conclusions}

With the improved availability of new glucose monitoring technologies, such as CGM and flash glucose monitoring, GV is becoming a more meaningful metric of glycemic control, and is without doubt now being recognized. Elaborating the role and mechanisms of GV in diabetic macrovascular and microvascular complications will be conducive to taking targeted measures in clinical practice and providing the crucial help for clinicians to manage the diabetes-related complications.

\begin{abstract}
Abbreviations
GV: Glycemic variability; FPG: Fasting plasma glucose; PPG: Postprandial glucose; CV: Coefficient of variation; SD: Standard deviation; VIM: Variation independent ofthe mean; MAGE: Mean amplitude of glycemic excursions; MAG: Mean absolute glucose; CONGA: Continuous overlapping net glycemic action; TIR: Time in range; MODD: Mean of daily differences; AGP: Average glucose profile; IQRs: Interquartile ranges; LBGl: Low blood glucose index; HBGI: High blood glucose index; ADRR: Average daily risk range; SMBG: Selfmonitoring of blood glucose; CGM: Continuous glucose monitoring; T2DM: Type 2 diabetes mellitus; HOMA-IR: Homeostasis model assessment of insulin resistance; IMT: Intima-media thickness; CVD: Cardiovascular disease; GLIAS-II: Glycemia in Acute Stroke II; IS: Ischaemic stroke; VADT: Veteran Affairs Diabetes Trial; CARDIA: Coronary Artery Risk Development in Young Adults; HFpEF: Heart failure with preserved ejection fraction; DN: Diabetic nephropathy; DPN: Diabetes peripheral neuropathy; DR: Diabetic retinopathy; CKD: Chronic kidney disease; T1DM: Type 1 diabetes mellitus; TAR:Time above range; TBR: Time below range; GLP-1 RA: Glucagon-like peptide 1receptor agonist; DPP4: Dipeptidyl-peptidase 4; SGLT2: Sodium glucosecotransporter 2.
\end{abstract}

\section{Acknowledgements}

The authors wish to acknowledge Wenqun Li from the Second Xiangya Hospital for editing of English grammar and syntax of the manuscript.

Disclosures

All authors report no relevant relationships to the content of this review paper

Authors' contributions

All authors participated in the writing and editing of this review article. All authors read and approved the final manuscript.

\section{Funding}

This work was supported by grants from Natural Science Foundation of Hunan Province (No. 2020JJ5513), Scientific Research Fund of Hunan Provincial Education Department (No. 19A418) and Scientific Research Fund Project of Hunan Provincial Health Commission (No. 20201973).

Availability of data and materials

Not applicable.

Ethics approval and consent to participate

Not applicable.

Consent for publication

All authors have approved the final manuscript for publication.

\section{Competing interests}

The authors declare that they have no competing interests.

\section{Author details}

${ }^{1}$ Department of Pharmacy, The Second Xiangya Hospital, Central South University, No. 139 Middle Renmin Road, Changsha 410011, Hunan, China. ${ }^{2}$ Institute of Clinical Pharmacy, Central South University, Changsha 410011, China. ${ }^{3}$ Institute of Clinical Medicine, The First Affiliated Hospital, University of South China, No. 69, Chuanshan Road, Hengyang 421001, Hunan, China.

Received: 6 November 2020 Accepted: 24 December 2020

Published online: 07 January 2021

References

1. American Diabetes Association. Clinical practice recommendations 2008. Diabetes Care. 2008;31(Suppl 1):12-54 
2. International Diabetes Federation. IDF Diabetes Atlas, 9th edn; 2019. https://www.diabetesatlas.org. Accessed 2019.

3. Sarwar N, Gao P, Seshasai SR, Gobin R, Kaptoge S, Di Angelantonio E, Ingelsson E, Lawlor DA, Selvin E, Stampfer M, et al. Diabetes mellitus, fasting blood glucose concentration, and risk of vascular disease: a collaborative meta-analysis of 102 prospective studies. Lancet. 2010;375(9733):2215-22.

4. Cavender MA, Steg PG, Smith SC Jr, Eagle K, Ohman EM, Goto S, Kuder J, Im K, Wilson PW, Bhatt DL. Impact of Diabetes mellitus on hospitalization for heart failure, cardiovascular events, and death: outcomes at 4 years from the reduction of atherothrombosis for Continued Health (REACH) Registry. Circulation. 2015;132(10):923-31.

5. Kannel WB, McGee DL. Diabetes and glucose tolerance as risk factors for cardiovascular disease: the Framingham study. Diabetes Care. 1979;2(2):120-6.

6. Papatheodorou K, Papanas N, Banach M, Papazoglou D, Edmonds M. Complications of diabetes 2016. J Diabetes Res. 2016;2016:6989453.

7. Santiago JV. Lessons from the diabetes control and complications trial. Diabetes. 1993;42(11):1549-54.

8. DeVries JH. Glucose variability: where it is important and how to measure it. Diabetes. 2013;62(5):1405-8.

9. Wang A, Liu X, Xu J, Han X, Su Z, Chen S, Zhang N, Wu S, Wang Y, Wang Y. Visit-to-visit variability of fasting plasma glucose and the risk of cardiovascular disease and all-cause mortality in the general population. J Am Heart Assoc. 2017;6(12):e006757.

10. Zhou JJ, Schwenke DC, Bahn G, Reaven P. Glycemic variation and cardiovascular risk in the veterans affairs diabetes trial. Diabetes Care. 2018;41(10):2187-94.

11. Lin CC, Yang CP, Li Cl, Liu CS, Chen CC, Lin WY, Hwang KL, Yang SY, Li TC. Visit-to-visit variability of fasting plasma glucose as predictor of ischemic stroke: competing risk analysis in a national cohort of Taiwan Diabetes Study. BMC Med. 2014;12:165.

12. Hirakawa $Y$, Arima $H$, Zoungas $S$, Ninomiya $T$, Cooper $M$, Hamet $P$, Mancia G, Poulter N, Harrap S, Woodward M, et al. Impact of visit-to-visit glycemic variability on the risks of macrovascular and microvascular events and all-cause mortality in type 2 diabetes: the ADVANCE trial. Diabetes Care. 2014;37(8):2359-65.

13. Hirsch IB. Glycemic variability and diabetes complications: does it matter? Of course it does! Diabetes care. 2015;38(8):1610-4.

14. Bergenstal RM. Glycemic variability and diabetes complications: does it matter? Simply put, there are better glycemic markers! Diabetes care. 2015;38(8):1615-21

15. Sun B, He F, Gao Y, Zhou J, Sun L, Liu R, Xu H, Chen X, Zhou H, Liu Z, et al. Prognostic impact of visit-to-visit glycemic variability on the risks of major adverse cardiovascular outcomes and hypoglycemia in patients with different glycemic control and type 2 diabetes. Endocrine. 2019;64(3):536-43.

16. Zhou Z, Sun B, Huang S, Zhu C, Bian M. Glycemic variability: adverse clinical outcomes and how to improve it? Cardiovasc Diabetol. 2020;19(1):102.

17. Frontoni S, Di Bartolo P, Avogaro A, Bosi E, Paolisso G, Ceriello A. Glucose variability: an emerging target for the treatment of diabetes mellitus. Diabetes Res Clin Pract. 2013;102(2):86-95.

18. Kovatchev BP. Metrics for glycaemic control-from HbA(1c) to continuous glucose monitoring. Nat Rev Endocrinol. 2017;13(7):425-36.

19. Gorst C, Kwok CS, Aslam S, Buchan I, Kontopantelis E, Myint PK, Heatlie G, Loke Y, Rutter MK, Mamas MA. Long-term glycemic variability and risk of adverse outcomes: a systematic review and meta-analysis. Diabetes care. 2015;38(12):2354-69.

20. Lachin JM, Bebu I, Bergenstal RM, Pop-Busui R, Service FJ, Zinman B, Nathan DM. Association of glycemic variability in type 1 diabetes with progression of microvascular outcomes in the diabetes control and complications trial. Diabetes Care. 2017;40(6):777-83.

21. Kilpatrick ES, Rigby AS, Atkin SL. A1C variability and the risk of microvascular complications in type 1 diabetes: data from the Diabetes Control and Complications Trial. Diabetes Care. 2008;31 (11):2198-202.

22. Rothwell PM, Howard SC, Dolan E, O'Brien E, Dobson JE, Dahlöf B, Sever PS, Poulter NR. Prognostic significance of visit-to-visit variability, maximum systolic blood pressure, and episodic hypertension. Lancet. 2010;375(9718):895-905.
23. Suh S, Kim JH. Glycemic variability: how do we measure it and why is it important? Diabetes Metab J. 2015;39(4):273-82.

24. Service FJ, Molnar GD, Rosevear JW, Ackerman E, Gatewood LC, Taylor WF. Mean amplitude of glycemic excursions, a measure of diabetic instability. Diabetes. 1970;19(9):644-55.

25. McDonnell CM, Donath SM, Vidmar SI, Werther GA, Cameron FJ. A novel approach to continuous glucose analysis utilizing glycemic variation. Diabetes Technol Ther. 2005;7(2):253-63.

26. Yau JW, Rogers SL, Kawasaki R, Lamoureux EL, Kowalski JW, Bek T, Chen SJ, Dekker JM, Fletcher A, Grauslund J, et al. Global prevalence and major risk factors of diabetic retinopathy. Diabetes Care. 2012;35(3):556-64.

27. Battelino T, Danne T, Bergenstal RM, Amiel SA, Beck R, Biester T, Bosi E, Buckingham BA, Cefalu WT, Close KL, et al. Clinical targets for continuous glucose monitoring data interpretation: recommendations from the international consensus on time in range. Diabetes Care. 2019;42(8):1593-603.

28. Molnar GD, Taylor WF, Ho MM. Day-to-day variation of continuously monitored glycaemia: a further measure of diabetic instability. Diabetologia. 1972;8(5):342-8.

29. Bailey T, Bode BW, Christiansen MP, Klaff LJ, Alva S. The performance and usability of a factory-calibrated flash glucose monitoring system. Diabetes Technol Ther. 2015;17(11):787-94.

30. Hoss U, Budiman ES. Factory-calibrated continuous glucose sensors: the science behind the technology. Diabetes Technol Ther. 2017;19(S2):44-s50.

31. Kovatchev BP, Cox DJ, Gonder-Frederick LA, Clarke W. Symmetrization of the blood glucose measurement scale and its applications. Diabetes Care. 1997;20(11):1655-8.

32. Fabris $C$, Patek SD, Breton MD. Are risk indices derived from CGM interchangeable with SMBG-based indices? J Diabetes Sci Technol. 2015;10(1):50-9.

33. Hill NR, Oliver NS, Choudhary P, Levy JC, Hindmarsh P, Matthews DR. Normal reference range for mean tissue glucose and glycemic variability derived from continuous glucose monitoring for subjects without diabetes in different ethnic groups. Diabetes Technol Ther. 2011;13(9):921-8

34. Danne T, Nimri R, Battelino T, Bergenstal RM, Close KL, DeVries JH, Garg S, Heinemann L, Hirsch I, Amiel SA, et al. International consensus on use of continuous glucose monitoring. Diabetes Care. 2017;40(12):1631-40.

35. Borot S, Benhamou PY, Atlan C, Bismuth E, Bonnemaison E, Catargi B, Charpentier G, Farret A, Filhol N, Franc S, et al. Practical implementation, education and interpretation guidelines for continuous glucose monitoring: a French position statement. Diabetes Metab. 2018;44(1):61-72.

36. Chico A, Aguilera E, Ampudia-Blasco FJ, Bellido V, Cardona-Hernández R, Escalada FJ, Fernández D, Gómez-Peralta F, González Pérez de Villar $\mathrm{N}$, Gorgojo JJ, et al. Clinical approach to flash glucose monitoring: an expert recommendation. J Diabetes Sci Technol. 2020;14(1):155-64.

37. Nusca A, Tuccinardi D, Albano M, Cavallaro C, Ricottini E, Manfrini S, Pozzilli P, Di Sciascio G. Glycemic variability in the development of cardiovascular complications in diabetes. Diab/Metab Res Rev. 2018;34(8):e3047.

38. Cardoso CRL, Leite NC, Moram CBM, Salles GF. Long-term visit-to-visit glycemic variability as predictor of micro- and macrovascular complications in patients with type 2 diabetes: The Rio de Janeiro Type 2 Diabetes Cohort Study. Cardiovasc Diabetol. 2018;17(1):33.

39. Takahashi H, Iwahashi N, Kirigaya J, Kataoka S, Minamimoto Y, Gohbara M, Abe T, Okada K, Matsuzawa Y, Konishi M, et al. Glycemic variability determined with a continuous glucose monitoring system can predict prognosis after acute coronary syndrome. Cardiovasc Diabetol. 2018;17(1):116.

40. Xia J, Yin C. Glucose variability and coronary artery disease. Heart Lung Circ. 2019;28(4):553-9.

41. Scott ES, Januszewski AS, O'Connell R, Fulcher G, Scott R, Kesaniemi A Wu L, Colagiuri S, Keech A, Jenkins AJ. Long-term glycemic variability and vascular complications in type 2 diabetes: post hoc analysis of the FIELD study. J Clin Endocrinol Metab. 2020;105(10):e3638-49.

42. Slieker RC, van der Heijden A, Nijpels G, Elders PJM, t Hart LM, Beulens JWJ. Visit-to-visit variability of glycemia and vascular complications: the Hoorn Diabetes Care System cohort. Cardiovasc Diabetol. 2019;18(1):170 
43. Liang S, Yin H, Wei C, Xie L, He H, Liu X. Glucose variability for cardiovascular risk factors in type 2 diabetes: a meta-analysis. J Diabetes Metab Disord. 2017;16:45.

44. Besch G, Pili-Floury S, Morel C, Gilard M, Flicoteaux G, Salomon du Mont L, Perrotti A, Meneveau N, Chocron S, Schiele F, et al. Impact of post-procedural glycemic variability on cardiovascular morbidity and mortality after transcatheter aortic valve implantation: a post hoc cohort analysis. Cardiovasc Diabetol. 2019;18(1):27.

45. Clement KC, Suarez-Pierre A, Sebestyen K, Alejo D, DiNatale J, Whitman GJR, Matthew TL, Lawton JS. Increased glucose variability is associated with major adverse events after coronary artery bypass. Ann Thorac Surg. 2019;108(5):1307-13.

46. Benalia M, Zeller M, Mouhat B, Guenancia C, Yameogo V, Greco C, Yao $H$, Maza $M$, Vergès $B$, Cottin $Y$. Glycaemic variability is associated with severity of coronary artery disease in patients with poorly controlled type 2 diabetes and acute myocardial infarction. Diabetes Metab. 2019;45(5):446-52.

47. Ito T, Ichihashi T, Fujita H, Sugiura T, Yamamoto J, Kitada S, Nakasuka $K$, Kawada Y, Ohte N. The impact of intraday glucose variability on coronary artery spasm in patients with dysglycemia. Heart Vessels. 2019;34(8):1250-7.

48. Pu Z, Lai L, Yang X, Wang Y, Dong $P$, Wang $D$, Xie Y, Han Z. Acute glycemic variability on admission predicts the prognosis in hospitalized patients with coronary artery disease: a meta-analysis. Endocrine. 2020;67(3):526-34.

49. Nusca A, Tuccinardi D, Proscia C, Melfi R, Manfrini S, Nicolucci A, Ceriello A, Pozzilli P, Ussia GP, Grigioni F, et al. Incremental role of glycaemic variability over $\mathrm{HbA1c}$ in identifying type 2 diabetic patients with high platelet reactivity undergoing percutaneous coronary intervention. Cardiovasc Diabetol. 2019;18(1):147.

50. Fuentes B, Pastor-Yborra S, Gutiérrez-Zúñiga R, González-Pérez de Villar N, de Rodríguez-Pardo CE, Gómez-de Frutos J, Laso-García MC, Gutiérrez-Fernández F, Ortega-Casarrubios M, et al. Glycemic variability: prognostic impact on acute ischemic stroke and the impact of corrective treatment for hyperglycemia. The GLIAS-III translational study. J Transl Med. 2020;18(1):414.

51. Gerbaud E, Darier R, Montaudon M, Beauvieux MC, Coffin-Boutreux C, Coste P, Douard H, Ouattara A, Catargi B. Glycemic variability is a powerful independent predictive factor of midterm major adverse cardiac events in patients with diabetes with acute coronary syndrome. Diabetes Care. 2019;42(4):674-81.

52. Tang $X$, Zhong J, Zhang H, Luo Y, Liu X, Peng L, Zhang Y, Qian $X$, Jiang B, Liu J, et al. Visit-to-visit fasting plasma glucose variability is an important risk factor for long-term changes in left cardiac structure and function in patients with type 2 diabetes. Cardiovasc Diabetol. 2019;18(1):50

53. Bancks MP, Carson AP, Lewis CE, Gunderson EP, Reis JP, Schreiner PJ, Yano Y, Carnethon MR. Fasting glucose variability in young adulthood and incident diabetes, cardiovascular disease and all-cause mortality. Diabetologia. 2019;62(8):1366-74.

54. Lee DY, Han K, Park S, Yu JH, Seo JA, Kim NH, Yoo HJ, Kim SG, Choi KM, Baik SH, et al. Glucose variability and the risks of stroke, myocardial infarction, and all-cause mortality in individuals with diabetes: retrospective cohort study. Cardiovasc Diabetol. 2020;19(1):144.

55. Yang $C D$, Shen $Y$, Ding FH, Yang ZK, Hu J, Shen WF, Zhang RY, Lu L, Wang XQ. Visit-to-visit fasting plasma glucose variability is associated with left ventricular adverse remodeling in diabetic patients with STEMI. Cardiovasc Diabetol. 2020;19(1):131.

56. Takao T, Matsuyama Y, Suka M, Yanagisawa H, Iwamoto Y. The combined effect of visit-to-visit variability in $\mathrm{HbAlc}$ and systolic blood pressure on the incidence of cardiovascular events in patients with type 2 diabetes. BMJ Open Diabetes Res Care. 2015;3(1):e000129.

57. Mo Y, Zhou J, Ma X, Zhu W, Zhang L, Li J, Lu J, Hu C, Bao Y, Jia W. Haemoglobin A1c variability as an independent correlate of atherosclerosis and cardiovascular disease in Chinese type 2 diabetes. Diab Vasc Dis Res. 2018;15(5):402-8.

58. Gu J, Fan YQ, Zhang JF, Wang CQ. Association of hemoglobin A1C variability and the incidence of heart failure with preserved ejection fraction in patients with type 2 diabetes mellitus and arterial hypertension. Hellenic J Cardiol HJC Hellenike kardiologike epitheorese. 2018;59(2):91-7.
59. Gu J, Pan JA, Fan YQ, Zhang HL, Zhang JF, Wang CQ. Prognostic impact of $\mathrm{HbA} 1 \mathrm{c}$ variability on long-term outcomes in patients with heart failure and type 2 diabetes mellitus. Cardiovasc Diabetol. 2018;17(1):96.

60. Yokota S, Tanaka H, Mochizuki Y, Soga F, Yamashita K, Tanaka Y, Shono A, Suzuki M, Sumimoto K, Mukai J, et al. Association of glycemic variability with left ventricular diastolic function in type 2 diabetes mellitus. Cardiovasc Diabetol. 2019;18(1):166.

61. Yang CD, Shen Y, Lu L, Yang ZK, Hu J, Zhang RY, Shen WF, Ding FH, Wang $\mathrm{XQ}$. Visit-to-visit $\mathrm{HbA}(1 \mathrm{c})$ variability is associated with in-stent restenosis in patients with type 2 diabetes after percutaneous coronary intervention. Cardiovasc Diabetol. 2020;19(1):133.

62. Li S, Tang X, Luo Y, Wu B, Huang Z, Li Z, Peng L, Ling Y, Zhu J, Zhong J, et al. Impact of long-term glucose variability on coronary atherosclerosis progression in patients with type 2 diabetes: a 2.3 year follow-up study. Cardiovasc Diabetol. 2020;19(1):146.

63. Yang CP, Lin CC, Li Cl, Liu CS, Lin CH, Hwang KL, Yang SY, Li TC. Fasting plasma glucose variability and $\mathrm{HbA} 1 \mathrm{c}$ are associated with peripheral artery disease risk in type 2 diabetes. Cardiovasc Diabetol. 2020;19(1):4.

64. Zhou JJ, Coleman R, Holman RR, Reaven P. Long-term glucose variability and risk of nephropathy complication in UKPDS, ACCORD and VADT trials. Diabetologia. 2020;63(11):2482-5.

65. Ceriello A, De Cosmo S, Rossi MC, Lucisano G, Genovese S, Pontremoli R, Fioretto P, Giorda C, Pacilli A, Viazzi F, et al. Variability in HbA1c, blood pressure, lipid parameters and serum uric acid, and risk of development of chronic kidney disease in type 2 diabetes. Diabetes Obes Metab. 2017;19(11):1570-8.

66. Lee $\mathrm{CL}$, Chen $\mathrm{CH}, \mathrm{Wu}$ MJ, Tsai SF. The variability of glycated hemoglobin is associated with renal function decline in patients with type 2 diabetes. Ther Adv Chronic Dis. 2020;11:2040622319898370.

67. Viazzi F, Russo GT, Ceriello A, Fioretto P, Giorda C, De Cosmo S, Pontremoli R. Natural history and risk factors for diabetic kidney disease in patients with T2D: lessons from the AMD-annals. J Nephrol. 2019;32(4):517-25.

68. Lee MY, Huang JC, Chen SC, Chiou HC, Wu PY. Association of HbA(1C) variability and renal progression in patients with type 2 diabetes with chronic kidney disease stages 3-4. Int J Mol Sci. 2018;19(12):4116.

69. Song KH, Jeong JS, Kim MK, Kwon HS, Baek KH, Ko SH, Ahn YB. Discordance in risk factors for the progression of diabetic retinopathy and diabetic nephropathy in patients with type 2 diabetes mellitus. J Diabetes Investig. 2019;10(3):745-52.

70. Akaza M, Akaza I, Kanouchi T, Sasano T, Sumi Y, Yokota T. Nerve conduction study of the association between glycemic variability and diabetes neuropathy. Diabetol Metab Syndr. 2018;10:69.

71. Yang J, Yang X, Zhao D, Wang X, Wei W, Yuan H. Association of time in range, as assessed by continuous glucose monitoring, with painful diabetic polyneuropathy. J Diabetes Investig. 2020. https://doi. org/10.1111/jdi.13394.

72. Pai YW, Lin CH, Lee IT, Chang MH. Variability of fasting plasma glucose and the risk of painful diabetic peripheral neuropathy in patients with type 2 diabetes. Diabetes Metab. 2018;44(2):129-34.

73. Yang CP, Li Cl, Liu CS, Lin WY, Hwang KL, Yang SY, Li TC, Lin CC. Variability of fasting plasma glucose increased risks of diabetic polyneuropathy in T2DM. Neurology. 2017:88(10):944-51.

74. Su JB, Zhao LH, Zhang XL, Cai HL, Huang HY, Xu F, Chen T, Wang XQ. $\mathrm{HbA1c}$ variability and diabetic peripheral neuropathy in type 2 diabetic patients. Cardiovasc Diabetol. 2018;17(1):47.

75. Lai YR, Huang CC, Chiu WC, Liu RT, Tsai NW, Wang HC, Lin WC, Cheng $\mathrm{BC}$, Su YJ, Su CM, et al. HbA1C variability is strongly associated with the severity of cardiovascular autonomic neuropathy in patients with type 2 diabetes after longer diabetes duration. Front NeuroSci. 2019;13:458.

76. Lai YR, Chiu WC, Huang CC, Tsai NW, Wang HC, Lin WC, Cheng BC, Su YJ, Su CM, Hsiao SY, et al. HbA1C variability is strongly associated with the severity of peripheral neuropathy in patients with type 2 diabetes. Front NeuroSci. 2019;13:90.

77. Christensen MMB, Hommel EE, Jørgensen ME, Fleischer J, Hansen CS. Glycemic variability and diabetic neuropathy in young adults with type 1 diabetes. Front Endocrinol. 2020;11:644.

78. Lu J, Ma X, Zhou J, Zhang L, Mo Y, Ying L, Lu W, Zhu W, Bao Y, Vigersky $R A$, et al. Association of time in range, as assessed by continuous glucose monitoring, with diabetic retinopathy in type 2 diabetes. Diabetes Care. 2018;41(11):2370-6. 
79. Zhao Q, Zhou F, Zhang Y, Zhou X, Ying C. Fasting plasma glucose variability levels and risk of adverse outcomes among patients with type 2 diabetes: a systematic review and meta-analysis. Diabetes Res Clin Pract. 2019;148:23-31.

80. Rosa L, Zajdenverg L, Souto DL, Dantas JR, Pinto MVR, Salles G, Rodacki M. HbA1c variability and long-term glycemic control are linked to diabetic retinopathy and glomerular filtration rate in patients with type 1 diabetes and multiethnic background. J Diabetes Complicat. 2019;33(9):610-5.

81. Schreur V, van Asten F, Ng H, Weeda J, Groenewoud JMM, Tack CJ, Hoyng CB, de Jong EK, Klaver CCW, Jeroen Klevering B. Risk factors for development and progression of diabetic retinopathy in Dutch patients with type 1 diabetes mellitus. Acta Ophthalmol. 2018;96(5):459-64.

82. Rama Chandran S, Tay WL, Lye WK, Lim LL, Ratnasingam J, Tan ATB, Gardner DSL. Beyond HbA1c: comparing glycemic variability and glycemic indices in predicting hypoglycemia in type 1 and type 2 diabetes. Diabetes Technol Ther. 2018;20(5):353-62.

83. Gómez AM, Muñoz OM, Marin A, Fonseca MC, Rondon M, Robledo Gómez MA, Sanko A, Lujan D, García-Jaramillo M, León Vargas FM. Different indexes of glycemic variability as identifiers of patients with risk of hypoglycemia in type 2 diabetes mellitus. J Diabetes Sci Technol. 2018;12(5):1007-15.

84. Gómez AM, Henao DC, Imitola Madero A, Taboada LB, Cruz V, Robledo Gómez MA, Rondón M, Muñoz-Velandia O, García-Jaramillo M, León Vargas FM. Defining high glycemic variability in type 1 diabetes: comparison of multiple indexes to identify patients at risk of hypoglycemia. Diabetes Technol Ther. 2019;21 (8):430-9.

85. Valente T, Arbex AK. Glycemic variability, oxidative stress and impact on complications related to type 2 diabetes mellitus. Curr Diabetes Rev. 2020;771:139-54.

86. Papachristoforou E, Lambadiari V, Maratou E, Makrilakis K. Association of glycemic indices (hyperglycemia, glucose variability, and hypoglycemia) with oxidative stress and diabetic complications. J Diabetes Res. 2020;2020:7489795

87. Ceriello A, Esposito K, Piconi L, Ihnat MA, Thorpe JE, Testa R, Boemi M, Giugliano D. Oscillating glucose is more deleterious to endothelial function and oxidative stress than mean glucose in normal and type 2 diabetic patients. Diabetes. 2008;57(5):1349-54.

88. Quagliaro L, Piconi L, Assaloni R, Martinelli L, Motz E, Ceriello A. Intermittent high glucose enhances apoptosis related to oxidative stress in human umbilical vein endothelial cells: the role of protein kinase $C$ and NAD(P)H-oxidase activation. Diabetes. 2003;52(11):2795-804.

89. Schisano B, Tripathi G, McGee K, McTernan PG, Ceriello A. Glucose oscillations, more than constant high glucose, induce p53 activation and a metabolic memory in human endothelial cells. Diabetologia. 2011;54(5):1219-26.

90. Keating ST, El-Osta A. Glycemic memories and the epigenetic component of diabetic nephropathy. Curr Diabetes Rep. 2013;13(4):574-81.

91. Groop PH, Forsblom C, Thomas MC. Mechanisms of disease: pathwayselective insulin resistance and microvascular complications of diabetes. Nat Clin Pract Endocrinol Metab. 2005;1 (2):100-10.

92. Del Guerra S, Grupillo M, Masini M, Lupi R, Bugliani M, Torri S, Boggi U, Del Chiaro M, Vistoli F, Mosca F, et al. Gliclazide protects human islet beta-cells from apoptosis induced by intermittent high glucose. Diabetes Metab Res Rev. 2007;23(3):234-8.

93. Costantino S, Paneni F, Battista R, Castello L, Capretti G, Chiandotto S, Tanese L, Russo G, Pitocco D, Lanza GA, et al. Impact of glycemic variability on chromatin remodeling, oxidative stress, and endothelial dysfunction in patients with type 2 diabetes and with target $\mathrm{HbA}(1 \mathrm{c})$ levels. Diabetes. 2017;66(9):2472-82.

94. Ceriello A, Esposito K, Piconi L, Ihnat M, Thorpe J, Testa R, Bonfigli AR, Giugliano D. Glucose "peak" and glucose "spike": impact on endothelial function and oxidative stress. Diabetes Res Clin Pract. 2008;82(2):262-7.

95. Brownlee M, Hirsch IB. Glycemic variability: a hemoglobin A1c-independent risk factor for diabetic complications. JAMA. 2006:295(14):1707-8.

96. Monnier L, Mas E, Ginet C, Michel F, Villon L, Cristol JP, Colette C. Activation of oxidative stress by acute glucose fluctuations compared with sustained chronic hyperglycemia in patients with type 2 diabetes. JAMA. 2006;295(14):1681-7.
97. Saisho Y. Glycemic variability and oxidative stress: a link between diabetes and cardiovascular disease? Int J Mol Sci. 2014;15(10):18381-406.

98. Di Flaviani A, Picconi F, Di Stefano P, Giordani I, Malandrucco I, Maggio P, Palazzo P, Sgreccia F, Peraldo C, Farina F, et al. Impact of glycemic and blood pressure variability on surrogate measures of cardiovascular outcomes in type 2 diabetic patients. Diabetes Care. 2011;34(7):1605-9.

99. Siegelaar SE, Barwari T, Kulik W, Hoekstra JB, DeVries JH. No relevant relationship between glucose variability and oxidative stress in well-regulated type 2 diabetes patients. J Diabetes Sci Technol. 2011;5(1):86-92.

100. Wentholt IM, Kulik W, Michels RP, Hoekstra JB, DeVries JH. Glucose fluctuations and activation of oxidative stress in patients with type 1 diabetes. Diabetologia. 2008;51(1):183-90.

101. Ratter JM, Rooijackers HM, Tack CJ, Hijmans AG, Netea MG, de Galan BE, Stienstra R. Proinflammatory effects of hypoglycemia in humans with or without diabetes. Diabetes. 2017;66(4):1052-61.

102. Gogitidze Joy N, Hedrington MS, Briscoe VJ, Tate DB, Ertl AC, Davis SN. Effects of acute hypoglycemia on inflammatory and pro-atherothrombotic biomarkers in individuals with type 1 diabetes and healthy individuals. Diabetes Care. 2010;33(7):1529-35.

103. Rodbard D. Continuous glucose monitoring: a review of recent studies demonstrating improved glycemic outcomes. Diabetes Technol Ther. 2017;19(S3):25-s37.

104. Avari P, Moscardo V, Jugnee N, Oliver N, Reddy M. Glycemic variability and hypoglycemic excursions with continuous glucose monitoring compared to intermittently scanned continuous glucose monitoring in adults with highest risk type 1 diabetes. J Diabetes Sci Technol. 2020;14(3):567-74.

105. Maiorino MI, Signoriello S, Maio A, Chiodini P, Bellastella G, Scappaticcio L, Longo M, Giugliano D, Esposito K. Effects of continuous glucose monitoring on metrics of glycemic control in diabetes: a systematic review with meta-analysis of randomized controlled trials. Diabetes Care. 2020;43(5):1146-56.

106. Figueira FR, Umpierre D, Casali KR, Tetelbom PS, Henn NT, Ribeiro JP, Schaan BD. Aerobic and combined exercise sessions reduce glucose variability in type 2 diabetes: crossover randomized trial. PLOS ONE. 2013;8(3):e57733.

107. Farabi SS, Carley DW, Smith D, Quinn L. Impact of exercise on diurnal and nocturnal markers of glycaemic variability and oxidative stress in obese individuals with type 2 diabetes or impaired glucose tolerance. Diab Vasc Dis Res. 2015;12(5):381-5.

108. Rafiei H, Robinson E, Barry J, Jung ME, Little JP. Short-term exercise training reduces glycaemic variability and lowers circulating endothelial microparticles in overweight and obese women at elevated risk of type 2 diabetes. Eur J Sport Sci. 2019;19(8):1140-9.

109. Figueira FR, Umpierre D, Bock PM, Waclawovsky G, Guerra AP, Donelli A, Andrades M, Casali KR, Schaan BD. Effect of exercise on glucose variability in healthy subjects: randomized crossover trial. Biol Sport. 2019;36(2):141-8

110. Ranjan A, Schmidt S, Damm-Frydenberg C, Holst JJ, Madsbad S, Nørgaard K. Short-term effects of a low carbohydrate diet on glycaemic variables and cardiovascular risk markers in patients with type 1 diabetes: a randomized open-label crossover trial. Diabetes Obes Metab. 2017:19(10):1479-84.

111. Ahola AJ, Forsblom C, Harjutsalo V, Groop PH. Dietary carbohydrate intake and cardio-metabolic risk factors in type 1 diabetes. Diabetes Res Clin Pract. 2019;155:107818.

112. Eiswirth M, Clark E, Diamond M. Low carbohydrate diet and improved glycaemic control in a patient with type one diabetes. Endocrinol Diabetes Metab Case Rep. 2018. https://doi.org/10.1530/EDM-18-0002.

113. Chang CR, Francois ME, Little JP. Restricting carbohydrates at breakfast is sufficient to reduce 24-hour exposure to postprandial hyperglycemia and improve glycemic variability. Am J Clin Nutr. 2019;109(5):1302-9.

114. Nishimura R, Osonoi T, Koike Y, Miyata K, Shimasaki Y. A randomized pilot study of the effect of trelagliptin and alogliptin on glycemic variability in patients with type 2 diabetes. Adv Ther. 2019;36(11):3096-109.

115. Bajaj HS, Venn K, Ye C, Patrick A, Kalra S, Khandwala H, Aslam N, TwumBarima D, Aronson R. Lowest glucose variability and hypoglycemia are observed with the combination of a GLP-1 receptor agonist and basal insulin (VARIATION study). Diabetes Care. 2017;40(2):194-200.

116. Park SE, Lee BW, Kim JH, Lee WJ, Cho JH, Jung CH, Lee SH, Suh S, Hur $\mathrm{GC}$, Kim SH, et al. Effect of gemigliptin on glycaemic variability in 
patients with type 2 diabetes (STABLE study). Diabetes Obes Metab. 2017:19(6):892-6.

117. Kim NH, Kim DL, Kim KJ, Kim NH, Choi KM, Baik SH, Kim SG. Effects of vildagliptin or pioglitazone on glycemic variability and oxidative stress in patients with type 2 diabetes inadequately controlled with metformin monotherapy: a 16-week, randomised, open label, pilot study. Endocrinol Metab (Seoul Korea). 2017;32(2):241-7.

118. Kim G, Oh S, Jin SM, Hur KY, Kim JH, Lee MK. The efficacy and safety of adding either vildagliptin or glimepiride to ongoing metformin therapy in patients with type 2 diabetes mellitus. Expert Opin Pharmacother. 2017;18(12):1179-86.

119. Al-Kuraishy HM, Sami OM, Hussain NR, Al-Gareeb Al. Metformin and/or vildagliptin mitigate type II diabetes mellitus induced-oxidative stress: the intriguing effect. J Adv Pharm Tech Res. 2020;11(3):142-7.

120. Famulla S, Pieber TR, Eilbracht J, Neubacher D, Soleymanlou N, Woerle HJ, Broedl UC, Kaspers S. Glucose Exposure and Variability with
Empagliflozin as Adjunct to Insulin in Patients with Type 1 Diabetes: Continuous Glucose Monitoring Data from a 4-Week, Randomized, Placebo-Controlled Trial (EASE-1). Diabetes Technol Ther. 2017;19(1):49-60.

121. Suzuki D, Yamada H, Yoshida M, Funazaki S, Amamoto M, Morimoto J, Hara K. Sodium-glucose cotransporter 2 inhibitors improved timein-range without increasing hypoglycemia in Japanese patients with type 1 diabetes: a retrospective, single-center, pilot study. J Diabetes Investig. 2020;11(5):1230-7.

\section{Publisher's note}

Springer Nature remains neutral with regard to jurisdictional claims in published maps and institutional affiliations.
Ready to submit your research? Choose BMC and benefit from:

- fast, convenient online submission

- thorough peer review by experienced researchers in your field

- rapid publication on acceptance

- support for research data, including large and complex data types

- gold Open Access which fosters wider collaboration and increased citations

- maximum visibility for your research: over $100 \mathrm{M}$ website views per year

At BMC, research is always in progress.

Learn more biomedcentral.com/submissions 